\title{
Přístupnost tělesné výchovy pro studenty se specifickými nároky na Masarykově univerzitě
}

\section{Accessibility of Physical Education for Students with Special Needs at Masaryk University}

\author{
Alexandr Zvonek \\ Středisko pro pomoc studentům se specifickými nároky \\ Masarykovy univerzity, Teiresiás, Brno, Česká republika
}

\section{Abstrakt:}

Na Masarykově univerzitě v současné době studuje 450 studentů se specifickými nároky (stav ke 31. 1. 2013), což je nejvíce mezi veřejnými vysokými školami v ČR. Jedná se převážně o studenty s postižením pohybovým, zrakovým, sluchovým ale i další. Stejně jako ostatní studenti mají právo, ač je otázka zda je vhodné takto slovo právo v takovéto souvislosti použit, na plnohodnotné zapojení do všech aktivit, které se studiem souvisejí, tzn. také do aktivit v oblasti tělesné výchovy a sportu. Tato práva vycházejí nejen z všeobecné legislativy, ale jsou v rámci Masarykovy univerzity ukotvena $i v$ internich dokumentech (např. Směrnice o studiu osob se specifickými nároky - Směrnice č. 04/03). Značnou část úkolì, které s naplñováním těchto práv souvisí (obecně se hovoři o zpř́stupněni studia), v praxi zajištuje celouniverzitní pracoviště - Středisko pro pomoc studentům se specifickými nároky MU, Teiresiás. V oblasti tělesné výchovy a sportu se jedná (vždy dle potřeby) jednak o zajištění podmínek pro zpř́stupnění standardní výuky tělesné výchovy a standardně nabizených sportovních aktivit a dále o vytvárení vhodných alternativ, neni-li zprístupnèni standardní nabidky z hlediska technického, metodologického aj. vhodné. V poslednich letech se na Masarykově univerzitě aktivně zapojuje do sportovni činnosti (at' již standardní nebo alterna- 
tivni) v průměru 37 rádných studentů se specifickými nároky za semestr, z toho někteři si zapíši více prededmètů tělesné výchovy v jednom semestru. Zajištěni prístupnosti znamená v praxi vyřešit řadu překážek na straně personální, na straně materiálního vybavení, dále př́stupnosti budov a jejich částí, ale také nap̌r. v oblasti vhodné studijní podpory (přistupnost didaktických a studijnich materiálü). Vedlo toho je někdy nezbytná také intervence $v$ oblasti motivace studenti̊ se specifickými nároky. Veškeré tyto aktivity se neobejdou bez odpovídající spolupráce, která je interně nezbytná především s Centrem univerzitního sportu Fakulty sportovních studii Masarykovy univerzity a externě pak s dalšimi státními i nestátními institucemi.

\section{Abstract:}

As of January 31, 2013, there are 450 special needs students currently studying at Masaryk University. This is the largest number of students with special needs among all Czech universities. These are students with visual, hearing or mobility impairment or other disabilities. As well as others, these students have the right (though the use of the word in this context is disputable) to fully participate in all activities pertaining to their studies, which include Physical Education and sports activities. These rights are not only contained in the general legislature, but they are also embedded in Masaryk University's internal documents (e. g. Rector's Directive on the Studies of Persons with Special Needs - Rector's Directive No. 04/03). A substantial part of the tasks connected with fulfilling these rights (and therefore ensuring accessibility of studies) is provided by Teiresias - the Support Centre for Students with Special Needs at Masaryk University. In the area of Physical Education and sports, this involves providing the conditions for accessibility of standard Physical Education and sports activities and creating alternative solutions if the former proves unsuitable for any reason (technical, methodological etc.). On the average, 37 special needs students a semester have been participating in sports activities (standard or alternative) in recent years; with some of them taking more than one Phy- 
sical Education course in a semester. Providing accessibility encompasses a number of obstacles; there are personnel issues, issues of material and equipment, accessibility of university buildings or suitable didactic and study materials. Sometimes also intervention into the motivation of special needs students is necessary. The activities of Teiresias are based on internal cooperation with the University Sports Centre of the Faculty of Sports, Masaryk University, and external cooperation with both governmental and non-governmental institutions.

Klíčová slova: Masarykovy univerzita, studenti se specifickými nároky, Středisko pro pomoc studentüm se specifickými nároky - Teiresiás, zpřistupněni tělesné výchovy a sportovních aktivit, standardní a alternativní nabidka tělesné výchovy a sportovních aktivit, překážky při zajištění přistupnosti, interní a externí spolupráce.

Key words: Masaryk University, students with special needs, Support Centre for Students with Special Needs - Teiresias, providing accessibility of sports activities and Physical Education, standard and alternative range of physical education and sports activities, obstacles in providing accessibility, internal and external cooperation.

Počty studentů se specifickými nároky, kam spadají především studenti s pohybovým a smyslovým (zrakovým a sluchovým) handicapem, na Masarykově univerzitě od roku 2000 (což je rok, kdy započala systematičtější intervence směrem $k$ těmto studentům) poměrně strmě stoupají. V roce 2013, konkrétně k 31. 1. 2013, bylo na Masarykově univerzitě evidováno 450 studentů se specifickými nároky (z celkového počtu více než 43000 řádných studentů), ale nemusí to být číslo zdaleka konečné. Počty studentů, především těch s méně závažným zdravotním postižením, budou v praxi spíše o něco vyšší, protože jejich evidence je založena především na tom, že sami své zdravotní postižení nebo zhoršený zdravotní stav a z něj vyplývající potřebu specifické podpory či specifické- 
ho přístupu oznámí. Někdy tato nepotřeba oznámení přetrvá jen do chvíle, kdy začnou být studijní nároky vyšší, nebo kdy narazí na problémy související s odlišností studia na vysoké škole např. ve srovnání s jejich dosavadní zkušeností ze sekundárního stupně vzdělávání. Těmi mohou být také požadavky kladené v oblasti tělesné výchovy. Tak jako tak jsou počty studentů se specifickými nároky na Masarykově univerzitě nejvyšší mezi veřejnými vysokými školami v ČR.

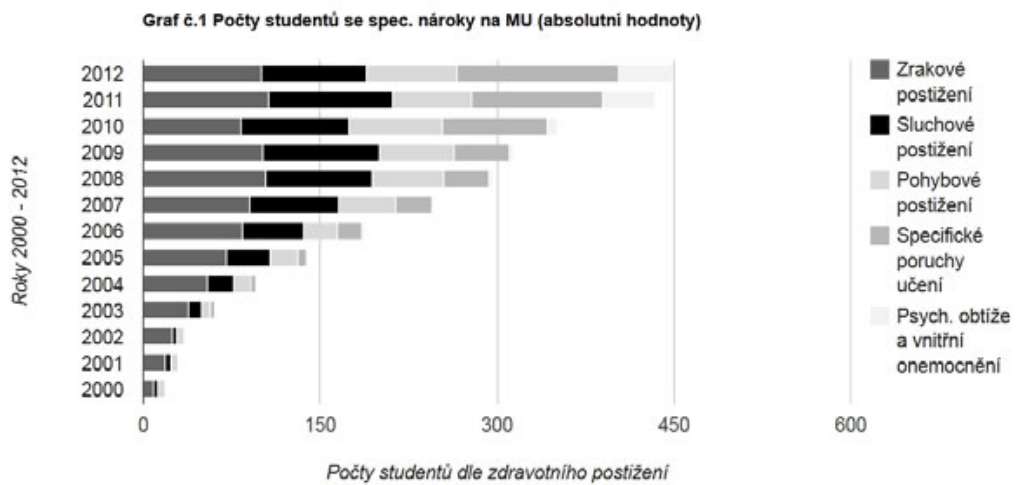

Obr. 1: Počty studentů se specifickými nároky na Masarykově univerzitě (absolutní hodnoty)

Speciální podmínky, práva a další náležitosti u studentů se specifickými potřebami na vysokých školách upravuje př́mo i nepřímo vícero obecně platných právních norem, ale také normy interní, platné pro konkrétní vysoké školy. Na Masarykově univerzitě je to především Směrnice rektora č. 4/2003 o studiu osob se specifickými nároky. Tato směrnice platí pro celou univerzitu jako celek, řadu konkrétních úkolů souvisejících s naplňováním těchto práv však řeší specializované celouniverzitní pracoviště - Středisko pro pomoc studentům se specifickými nároky, Teiresiás. Jeho aktivita vychází především z potřeb univerzity jako cel- 
$\mathrm{ku}, \mathrm{z}$ její zodpovědnosti vůči těmto studentům, z aktivity jednotlivých zaměstnanců, vyučujících, nejen tedy z potřeb a popudu studentů samotných. Základní úkol tohoto pracoviště by bylo možné shrnout jako "zodpovědnost za zpř́istupnění studia”. V praxi to znamená řadu aktivit, které spadají do mnoha různých oblastí, at' už se jedná o záležitosti architektonické, technické, metodologické, asistenční, publikační aj. Z logiky věci, je-li součástí studia na Masarykově univerzitě také tělesná výchova, zasahuje působnost pracoviště také do této oblasti.

Pokud bychom měli ve zkratce a trochu zjednodušeně shrnout situaci v oblasti tělesné výchovy na Masarykově univerzitě: je organizována, až na výjimky, pro všechny studenty prezenční formy studia. Studenti mají během svého studia (v libovolném semestru) získat dva zápočty $\mathrm{z}$ předmětů tělesné výchovy. At’ již se jedná o předměty s pravidelnou semestrální výukou, nebo o letní či zimní kurzy. Nabídka předmětů i kurzů je široká, zahrnuje jak individuální, tak i kolektivní sporty. Student si volí předmět či kurz dle svých preferencí a časových možností. Vedle toho je možné požádat o osvobození ze zdravotních důvodů, popř. také z důvodů vlastní vrcholové sportovní činnosti aj. Dále si mohou studenti volit, pokud mají zájem aktivněji sportovat, také z nabídky placené formy sportovních aktivit (opět předměty s pravidelnou semestrální výukou a kurzy). U této formy není nabídka omezena žádnými podmínkami, je určena všem studentům Masarykovy univerzity bez ohledu na typ studia aj. I za tyto předměty získávají studenti zápočty a kredity (tyto ale nenahrazují předměty povinné tělesné výchovy). Vedle toho se konají také různé jednorázové sportovní akce, nabízené širokému spektru zájemců. Za organizaci a výuku sportovních aktivit na Masarykově univerzitě zodpovídá Centrum univerzitního sportu Fakulty sportovních studií.

$Z$ výše uvedeného již také ve vztahu ke sportovním aktivitám vyplývají úkoly Střediska Teiresiás. Ty můžeme rozdělit do dvou částí, a to zajištění podmínek pro zpřístupnění standardní výuky tělesné výchovy a standardní nabídky sportovních aktivit a vytváření vhodných alternativ, není-li zpř́istupnění standardní nabídky z hlediska technického, metodologického aj. možné, nebo není-li v důsledku nedostatečného příno- 
su pro studenta vhodné. Konkrétní řešení, zda zajistit zpř́istupnění standardní výuky nebo preferovat alternativu, je otázkou řady faktorů, které budou zmíněny ještě dále, ale jistě je také otázkou rozhodnutí samotného studenta. $\mathrm{V}$ případě zajištění príístupnosti standardní výuky to $\mathrm{v}$ praxi znamená, vedle informování vyučujícího, nejčastěji zajištění osobní či odborné asistence, popř. intervenci směřující k odbourání komunikačních bariér, což je nejčastěji zajištění tlumočení do českého znakového jazyka u studentů se sluchovým postižením. Osobní asistence je zajištěna opět dle konkrétních potřeb. Může zahrnovat doprovod do místa výuky, pomoc při překonání architektonických bariér v místě, pomoc při prostorové orientaci (studenti se zrakovým postižením), osobní pomoc při využití sociálního zázemí, nebo také souvislou př́mou pomoc při výuce (u manipulace s předměty, pomoc při vykonávání pohybové aktivity např. u jógy, plavání, lyžování atd.). Tato může být omezena jen na začátek a konec výuky, celou úvodní hodinu, nebo několik prvních hodin výuky a posléze již student zvládá veškeré náležitosti samostatně, jindy je intervence soustavná po celou dobu výuky, po celou dobu semestru nebo konání kurzu. Vše je vždy záležitost ryze individuální, závislá nejen na konkrétním studentovi, ale také na konkrétním místě i sportovní aktivitě a do jisté míry také na požadavcích vyučujícího.

Druhou zajišstovanou možností je nabídka alternativních předmětů tělesné výchovy, které spadají organizačně pod Centrum univerzitního sportu Fakulty sportovních studií, ale odborně jsou garantovány Střediskem Teiresiás. Náplň u těchto předmětů má jiný charakter, didaktické a metodické postupy jsou odlišné, nabízí se speciální sportovní aktivity s využitím speciálních sportovních pomůcek atd. Tato nabídka se postupně rozšiřuje o nové předměty, v následujícím semestru se chystáme napřr. otevríit předmět zaměřený na handbike cyklistiku studentů s pohybovým postižením. Aktuálně se nabízí:

- Futsal pro nevidomé.

- Tandemová kola pro studenty se zrakovým postižením.

- Aplikovaný stolní tenis - showdown pro studenty se zrakovým postižením. 
- Horostěna pro studenty se zrakovým a sluchovým postižením.

- Zdravotní tělesná výchova pro studenty se zrakovým postiŽením.

- Tanec pro studenty se zrakovým postižením.

- Plavání pro studenty s pohybovým postižením.

- Pohybové aktivity pro studenty s poruchami hybnosti.

- Florbal pro studenty se sluchovým postižením.

- Horská kola pro studenty se sluchovým postižením.

- Alternativní pohybové aktivity a hry.

$\mathrm{K}$ tomu je třeba připočíst nabídku letních a zimních výcvikových kurzů pro studenty se zdravotním postižením, které zahrnují např. lyžování na monoski, kurzy vodní turistiky, vysokohorskou turistiku na sněžnicích, cykloturistiku na tandemových kolech, cykloturistiku na handbike aj.

I když se zdánlivě některé z nabízených předmětů neliší z hlediska přístupnosti od standardních možností, záludnosti mohou spočívat $\mathrm{v}$ malých detailech, jakým je např. hloubka bazénu v př́ípadě plavání studentů s pohybovým postižením (musí být menší, aby byla umožněna práce asistentů), dostupnost bezbariérového ubytování a sociálního zázemí na putovních napřr. vodáckých kurzech, zajištění přepravy vozíčků, jiná časová náročnost pro zvládnutí pohybové dovednosti bez možnosti zrakové korekce, aj.

Obecně se dá říci, že organizačně jednodušší (i když zároveň obecně finančně náročnější) je nabídka individuálních sportovních aktivit, kdy může činnost vykonávat student sám s lektorem (př. tandemová kola), popř. ve dvojicích (př. showdown). Pokud jde o aktivity kolektivní, jsou limity dány počtem zájemců (studentů) o danou sportovní aktivitu v rámci univerzity. $\mathrm{Na}$ druhou stranu ale nelze opomíjet faktor sociální, kdy možnost společného sportování vytváří nebo upevňuje vazby v rámci dané skupiny studentů, nebo komunity, pokud mluvíme o neslyšících uživatelích znakového jazyka. Je to pro ně příležitost přirozeného 
setkávání v komunikačně bezbariérovém prostředí a sport tak sám o sobě může být až na druhém místě. Pokud se podíváme na statistiku sportujících studentů se specifickými nároky v jednotlivých semestrech, zjistíme, že je to suma relativně vysoká v poměru k počtům studentů:

Obr. 2: Počty studentů se specifickými nároky na Masarykově univerzi-

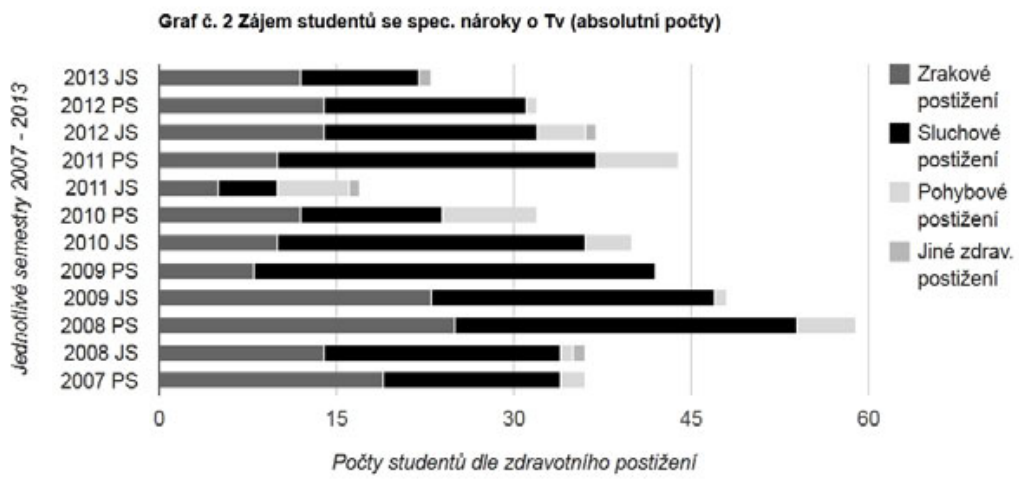

tě (absolutní hodnoty)

Zajímavým srovnáním může být, kolik studentů preferuje nabídku alternativní (speciální) tělesné výchovy a kolik standardní tělesné výchovy. Zcela objektivní srovnání je ovšem obtížné z více důvodů. Jedním $\mathrm{z}$ nich je napřr. fakt, že část studentů si v rámci semestru zapíše více předmětů, jak z nabídky alternativní tak i standardní tělesné výchovy (což je obecně dobře, protože to může být signálem volby na základě individuálního zájmu) a dále také proto, že nabídka standardních a především alternativních předmětů tělesné výchovy se mění, popř. rozšiřuje. Vedle toho je také otázkou pro volbu míra nezbytného zpřistupnění, tedy v jaké míre se mohou studenti s konkrétním zdravotním postižením zapojit do standardně nabízené aktivity. U lehčího zdravotního postižení nemusí být omezení v podstatě žádné, nebo je minimální, takže se dá předpoklá- 
dat volba z celé škály nabízených předmětů tělesné výchovy (standardních i alternativních). Naopak u těžšího zdravotního postižení jsou požadavky na přizpůsobení či přístupnost vyšší, takže zajištění přístupnosti nebo specifičnost předmětu hraje při jeho volbě zásadní, popř. jedinou roli. Jistě, pokud také pomineme fakt, že některé sportovní aktivity nemohou být s ohledem na omezení dané konkrétním zdravotním postižením studentům zpř́istupněny vůbec.

Obr. 3: Preference standardní/alternativní tělesné vv́chovv u studentů

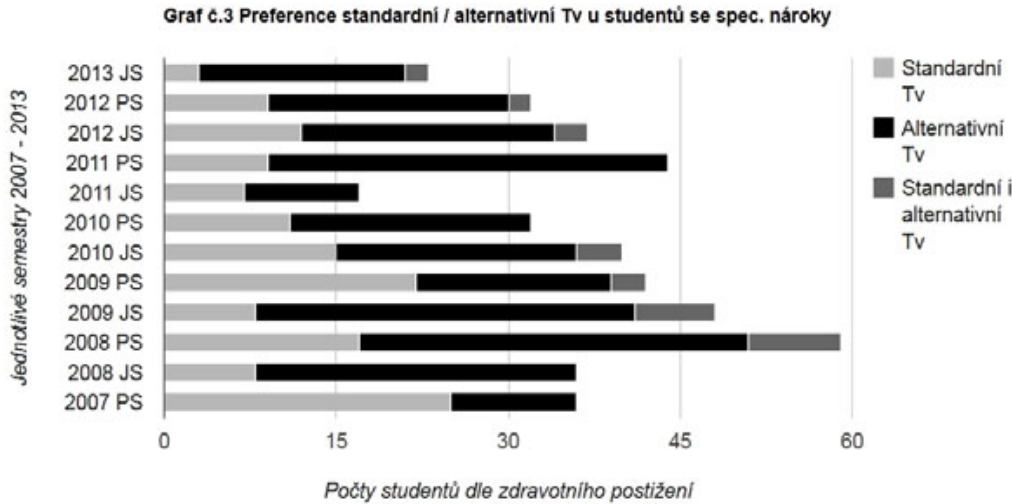

se specifickými nároky na Masarykově univerzitě

Pokud bychom měli shrnout největší obtíže, které je při organizaci tělesné výchovy pro studenty se specifickými nároky na Masarykově univerzitě třeba řešit, jsou to:

- Dostupnost/zajištění lektorů s potřebnou odbornou erudicí a především vlastní zkušeností s danou aktivitou a dostatečnou praxí, kteří jsou schopni vést výuku s očekávanou kvalitou tak, aby plně reflektovala aktuální potenciál studentů a dále jej rozvíjela. Zde je třeba poznamenat, že se jistě před- 
pokládá také funkční oboustranná komunikace s ohledem na specifika konkrétní skupin zdravotního postižení.

- Stejné předpoklady pro zvládnutí specifických činností se očekávají od dalšího personálu (asistentů). Zde se nabízí možnost specializovaného proškolení (např. pro oblast prostorové orientace aj. zajištěné např. přímo Střediskem Teiresiás), teoretická a především praktická připravenost je ale nezbytná.

- S výše uvedeným př́mo souvisí také dostupnost vhodně koncipovaných didaktických a metodických materiálů pro jednotlivé sportovní aktivity. Je potřeba počítat s určitým teoretickým základem jak pro studenty, tak i pro (budoucí) lektory či asistenty. Tento materiál by navíc měl být $\mathrm{v}$ takové formě, která je studentům prístupná.

- Dostupnost/zajištění speciálního sportovního vybavení, které samo o sobě navíc není levnou záležitostí. Někdy je navíc třeba řešit potíže, které souvisí s nízkou variabilitou a tedy s menší mírou univerzálnosti pro využití takového vybavení. Nejde o vybavení individuální (i když část studentů využívá své vlastní), ale je třeba zohlednit, že je využívá řada studentů s různými tělesnými proporcemi, s různým typem postižení a tedy různou mírou potřeby přizpůsobení.

- Dostupnost/prístupnost vhodných prostor pro danou sportovní aktivitu. Je třeba zohlednit potřeby cílové skupiny a míru bezbariérovosti prostor. Nejde jen o zjednodušený pohled, “jak se tam dostane vozíčkáŕr”, ale také o řadu souvisejících věcí, jako je dostupnost sociálního zázemí (šatny, toalety, sprchy), jakou míru samostatnosti v pohybu prostory nabízí. Různé skupiny studentů mají různé potřeby, takže je třeba se ptát, jak je členitá tělocvična, kde se budou pohybovat studenti se zrakovým postižením, jakou má akustiku atd. Podobné věci, především ubytování spolu s potřebnou logistikou, je tř̌eba řešit v př́padě kurzů. Málokdy se nabízí vyho- 
vující bezbariérové ubytování pro početnější skupinu studentů, navíc v místě, které je vhodné pro provozování konkrétní sportovní činnosti (napřr. vzdálenost od lyžařského svahu ve vztahu ke studentům s pohybovým postižením).

- Otázka kolektivních sportů již byla zmíněna na jiném místě tohoto textu. Ačkoliv má kolektivní sport významné postavení i z hlediska sociálního, často se naráží na problém spojený s omezeným počtem studentů (řešením je spolupráce se sportovními kluby či organizacemi zdravotně postižených, popř. zapojení studentů bez zdravotního postižení), nebo na problém nedostatečného množství speciálního sportovního vybavení.

- Specifický “problém” představují časové možnosti i zájem a motivace samotných studentů ke sportovní činnosti. S ohledem na organizaci studia a také vyšší míru individuální výuky není snadné najít všem vyhovující čas pro konání výuky tělesný výchvoy, zejm. pokud jde o kolektivní sporty. Studentů není tolik, aby se vždy podařilo kapacitu naplnit. S otázkou zájmu a motivace studentů je spojena jejich dosavadní zkušenost. Nejde jen o sport jako takový, zkušenost s ním, ale spíše o to, aby nebyli omezováni organizačně, aby např. prostory či ubytování skutečně vyhovovaly potřebám, personál byl znalý, zkušený a připravený, komunikace bezproblémová, podmínky pro sportovní činnost adekvátní atd.

Zajištění přístupnosti tělesné výchovy na Masarykově univerzitě by se neobešlo bez patřičné spolupráce, a to jak v rámci Masarykovy univerzity, tak i spolupráce meziuniverzitní a mimouniverzitní. V prŕípadě spolupráce $v$ rámci Masarykovy univerzity se jedná především o spolupráci v oblasti organizační, a to s Centrem univerzitního sportu Fakulty sportovních studií a popř. přímo s Fakultou sportovních studií samotnou. Organizačně se nabízí možnost snížit limit kapacity dané seminární skupiny, je-li to pro zajištění výuky vhodné, lze využít studentů se speciál- 
ními dovednostmi v rámci praxe aj. Také spolupráce s nejrůznějšími organizacemi i soukromými subjekty směřuje do oblasti personální, tzn. zajištění odborně erudovaných lektorů, proškolených asistentů, pokud tito nejsou v řadách zaměstnanců Masarykovy univerzity či jejich počet je nedostačující, ale dále také k zajištění oblasti materiální, což znamená zapůjčení speciálního sportovního vybavení, zajištění specializované dopravy, bezbariérového ubytování, atd. Za ně by bylo možné jmenovat např. Centrum aplikovaných aktivit Fakulty tělesné kultury Univerzity Palackého, občanská sdružení Paraple, Sportabily, Kontakt bB, Centrum handicapovaných lyžařŭ, Paracentrum Fénix, Tandem Brno, Avoy MU Brno, firmu Singing Rock a další.

Pokud vše shrneme, zajištění plné přístupnosti v oblasti tělesné výchovy a sportovních aktivit není zcela triviální záležitostí a koneckonců ani záležitostí levnou, ale je i přes svoji časovou a organizační náročnost možné. Předpokladů, které je třeba naplnit, je celá řada, povětšinou byly zmíněny. Patří k nim také př́prava specialistů, výměna zkušeností a vzájemná spolupráce.

\section{KONTAKT:}

Mgr. et Bc. Alexandr Zvonek, Ph.D., zvonek@teiresias.muni.cz 